Article

\title{
Territorial Cohesion in Rural Areas: An Analysis of Determinants in the Post-Economic Crisis Context
}

\author{
Pedro Sánchez-Zamora *iD and Rosa Gallardo-Cobos ${ }^{(D)}$ \\ Department of Agricultural Economics, Sociology and Policy, ETSIAM, Universidad de Córdoba, \\ 14014 Córdoba, Spain; rosagallardo@uco.es \\ * Correspondence: pedro.sanchez@uco.es; Tel.: +34-957-21-84-44
}

Received: 8 April 2020; Accepted: 1 May 2020; Published: 7 May 2020

\begin{abstract}
One of the main consequences of the impacts of the past economic and financial crisis, which began in 2007-2008, has been the increase in inequalities between countries, regions, and territories of the EU. In the rural sphere, these disparities are not only observed in an urban-rural dichotomy, but are also evident between rural-rural territories. In this context, it is relevant to develop research based on the concept of territorial cohesion aimed at overcoming the development challenges faced by different types of rural territories. This paper addresses the empirical analysis of territorial cohesion in the rural areas of Andalusia (Spain), one of the European regions most affected by the economic crisis. To this effect, a methodology was designed that measures the level of territorial cohesion of different types of rural territories and identifies the factors that influence this cohesion in each case. The results show that factors such as employment and innovation, economic diversification, availability of natural resources and environmental quality, or information and communication technologies (ICTs) contribute to territorial cohesion in rural areas.
\end{abstract}

Keywords: territorial cohesion; rural areas; territorial disparities; cohesion factors; composite indices; Spain

\section{Introduction}

The promotion of economic, social, and territorial cohesion has been one of the main pillars on which the construction of the European Union (EU) rests. This general principle has been expressed over the years through the objectives and priorities that have guided the Union's successive strategic guidelines in each programming period [1]. Currently, this is still a relevant issue on the current European political agenda, as reflected in its 'Europe 2020' growth strategy [2], which was designed based on the conviction that territorial coordination is a strategic factor on the path to inclusive economic growth [3].

However, despite the past and present efforts of EU policies to achieve territorial cohesion and the achievements in this regard that have been made in different stages and time contexts [4-8], the reality is that European territories suffer from many important territorial imbalances at various scales and of very different types [9]. The most recent EU enlargement and, above all, the recent financial and economic crisis of 2007-2008 that devastated most European regions and countries, have been identified as the main elements that have contributed to increasing current territorial inequalities $[1,10,11]$. Indeed, previous research has concluded that periods of economic prosperity stimulate regional convergence dynamics, while situations of crisis or recession lead to divergent territorial processes [12-15]. These situations occur between countries, but also between regions and territories belonging to the same country [16]. The trajectory followed by the region of Andalusia during the economic crisis (with unemployment rates tripling) is a clear example of this, where disparities 
can be observed not only in comparison with other Spanish and European regions, but also internally between their territories.

In addition to the analysis of inequalities between countries, regions, and territories, some authors point to the need for this type of study in rural areas, taking advantage of the close relationship between European regional policy and rural development policy $[17,18]$. In effect, the rural milieu is diverse, the potential ways of development are multiple, and the disparities between rural-rural territories are a reality [19]. In the case of Andalusia, previous studies show that there are indeed significant inequalities between the different types of rural territories [20,21].

In the rural milieu, these inequalities take many forms that reinforce each other, both from the individual perspective with vertical inequalities, and from the collective perspective with horizontal inequalities [22]. It is in this second dimension where inequalities between rural territories can be found when these are understood as the result of a social construction.

In this context, it is useful to apply the concept of territorial cohesion because it allows the development of the territory to be geared towards meeting the major challenges it faces [23]. This is a concept that has been gaining ground in the political agenda of the institutions since its origin within the European Union (EU) in the 1990s. This is mainly reflected through three key elements: (i) The incorporation of the territorial dimension in the Second Cohesion Report [24]; (ii) the publication of the Green Paper on Territorial Cohesion [25]; and (iii) the regulatory recognition given to territorial cohesion in the Lisbon Treaty as one of the three fundamental pillars of EU Regional Policy.

Despite the importance that the concept of territorial cohesion has been acquiring within the EU and the progress made in the fields of different scientific disciplines to clarify its meaning, several authors warn of the inaccuracy that still exists in the definition of this concept [26-31]. This lack of definition makes it even more difficult to measure the territorial cohesion of a given territory, but it does arouse scientific interest in advancing the design of methodologies that can be used to analyze it and thus provide new knowledge.

Under these circumstances-the context of territorial imbalances, the need to move towards convergence of territories, and the difficulty of measuring a concept with a markedly abstract component-give rise to the need to undertake research capable of addressing the analysis and measurement of territorial cohesion [32]. Among the few studies that have empirically addressed the measurement of territorial cohesion, apart from those carried out by the European Spatial Planning Observation Network (ESPON program), those conducted at the European level [1,33-37] and in Latin America $[23,38]$ stand out.

This is a series of studies in which territorial cohesion is measured in different contexts and at different territorial scales, but which in no case focus on the rural environment. Similarly, although all of the works contemplate the diversity of contexts in which the analyzed territorial units are developed, this has not been sufficiently incorporated in the empirical analysis. This has led to the fact that, on many occasions, very different regions and territories have been contemplated as a homogeneous 'whole'. For this reason, despite these advances, which undoubtedly represent an important methodological reference, it is of interest to develop studies that consider the analysis of territorial cohesion and the search for factors that affect it through territories with characteristics of homogeneity among themselves, both in their initial conditions and in their level of territorial resources [21].

Hence, the main objective of this paper is to conduct an analysis of territorial cohesion in rural areas of Andalusia, one of the European regions most affected by the past economic crisis, considering the different contexts in which their territories are developing. Specifically, the purpose is to measure the territorial cohesion of the different rural areas and identify the main factors associated with it. The identification of these specific factors for each type of territory is useful in guiding the design of specific policies that seek a harmonious and balanced development of rural areas. 


\section{Territorial Cohesion: Progress in the Concept to Articulate Its Measurement}

The concept of territorial cohesion emerges explicitly and in detail in the Second Cohesion Report [24], during Michel Barnier's mandate as European Commissioner for Regional Policy [39]. Since then, several works have addressed the analysis of this term, giving rise to a broad debate on its meaning. The main contributions made in this regard include: (i) Those that deepen the evolution of the conceptualization of the term, taking into account its French roots [40], the evolution of the European model of society [41], the new forms of governance [42], the principle of subsidiarity [43], and its link with sustainable development [44]; (ii) those that highlight the diversity of paths to define territorial cohesion, giving rise to multiple conceptualizations [45]; (iii) those that focus on the analysis of policy objectives [46] and on the establishment of principles and guidelines for effective policy implementation [47-49]; and (iv) those that establish a conceptual interpretation and provide a methodology of analysis $[23,35,50]$.

In spite of everything, the scientific literature shows a lack of consensus on the existence of a precise and widely accepted definition of the term 'territorial cohesion' and, as a result, from an operational and practical point of view, calls for progress in identifying the main dimensions and elements that make it up [34,51]. In order to identify these dimensions, some authors stress the need to first consider the implications of studying the analytical parts of the term 'territory' $[52,53]$. Accordingly, in the field of disciplines such as human geography or development economics, territory can be understood as a metric topographic space characterized by three elements or subsystems [54-59]: (i) Specific territorial resources available to the territory; (ii) territorial actors or agents (the State, civil society and associations, and private actors); and (iii) institutional arrangements that articulate the processes of transformation and development aimed at solving the common or specific problems faced by territories. The relationship established between these three elements is decisive in the processes of territorial convergence (or divergence) and must therefore be considered in cohesion analyses.

Based on these elements and on those provided in other studies, mainly developed by the European ESPON program [60-62], but also by the European Commission [63-65] and by researchers in the field of geography and economics [35,51], five basic dimensions can be established that provide theoretical support for the design of a methodology to measure territorial cohesion:

1. Economic dimension: As a fundamental basis for addressing the main challenges facing territories (i.e., the constant increase in global competition) and thus contributing to the ultimate objectives of growth and development [66-69].

2. Social dimension: Founded on the skills and abilities of individuals and their ability to establish relationships with other territorial actors through the formation of social networks. These networks act as a link for the deployment of economic initiatives aimed at ensuring the population's well-being [70,71].

3. Environmental dimension: Based on the recognition that the environment is the support of life. Therefore, environmental integration must be made effective in development processes, placing this dimension on the same level of value as economic and social issues $[62,68,69]$.

4. Institutional dimension: Understood as the regulatory framework under which formal and informal agreements are made to guarantee the proper functioning of the system and the development of the other dimensions. Relational capital and governance are key elements in this sphere [72-74].

5. Integrated spatial development dimension: Based on the principles of balanced territorial development aimed at promoting a polycentric territorial structure, both in terms of the morphology of territories and the relationships established between the settlements or municipalities that comprise them $[64,68]$.

The identification of these dimensions clarifies the meaning of the concept, but, above all, it enables the most appropriate components to be associated with each dimension in order to measure territorial cohesion accordingly. Figure 1 shows the analytical model used for this purpose. 


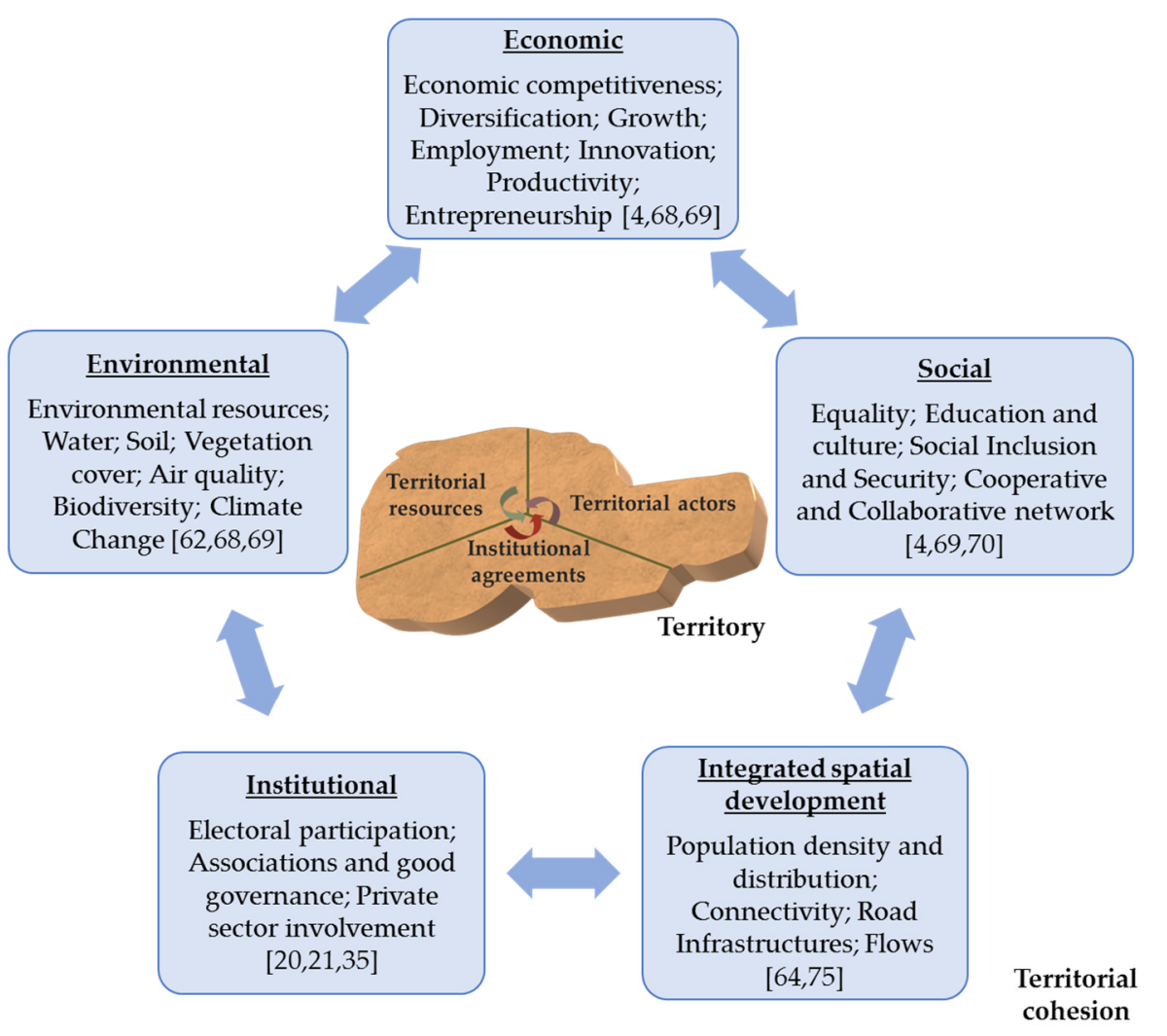

Figure 1. Analytical model: Dimensions and variables associated with territorial cohesion.

\section{Methodology}

\subsection{Research Scope and Unit Analysis}

The geographical area of the research is the rural milieu of Andalusia. This is a Spanish region (NUTS 2) located in southern Europe, at the gateway to the African continent (Figure 2). It is one of the most important regions in the EU, not only because of its strategic location, but also because of its large size in terms of surface area (it occupies $87,597 \mathrm{~km}^{2}$ ) and population (with over 8.4 million inhabitants), which places it ahead of many European countries.

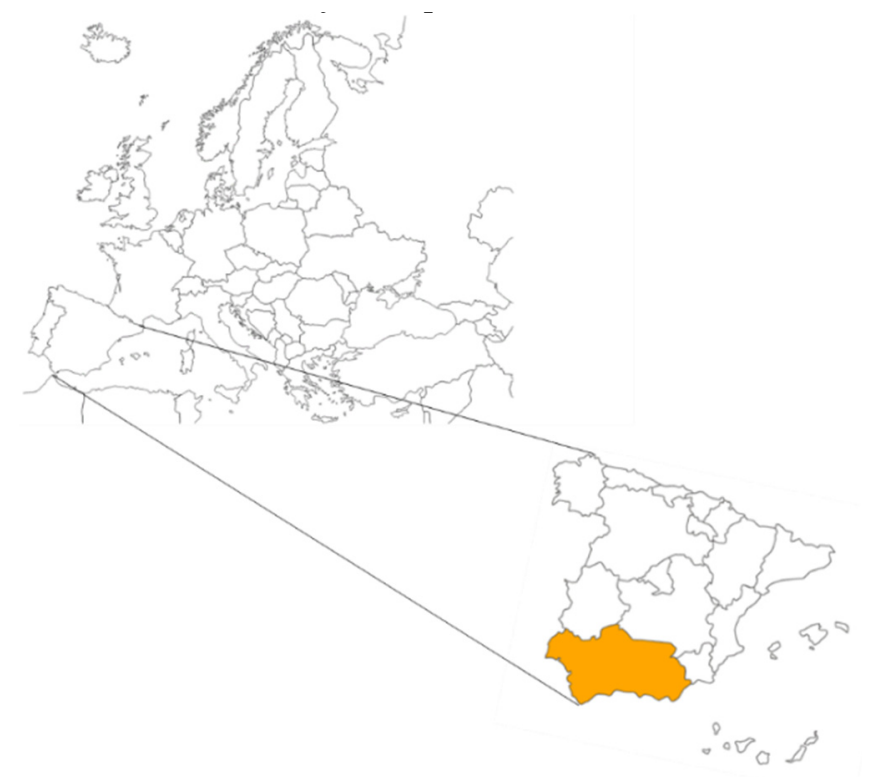

Figure 2. Location of the research area (shaded area. 
This is a region with a markedly rural character, generally characterized by (i) an economy based on the important role played by the agricultural sector and the agri-food industry; (ii) the presence of a multitude of associative networks of different kinds and different areas of activity that are deeply rooted in the territory; (iii) the richness of its ecosystems, natural spaces, and biodiversity; (iv) the existence of a varied network of institutions that facilitate the processes of governance and development of territories; and (v) a correct territorial articulation based on the presence of a close rural-rural and rural-urban interrelationship that facilitates an adequate demographic balance.

The greater or lesser presence of each of these elements and the multiple relationships that can be established between them gives the Andalusian rural milieu one of its main characteristics, heterogeneity. In fact, the current rural space is the product of history, of movements of polarization, of spatial planning, of an intense process of development through the implementation of European initiatives and policies, of its integration into the world market, and, more recently, of its response to external factors, such as the economic crisis. This crisis has had an impact on the dynamics of transformation in this region, causing a wide diversity of territorial dynamics, and thus increasing the disparity and inequality between its rural territories [21,75,76]. All of these characteristics highlight the opportunity and suitability of conducting an analysis of territorial cohesion in this geographical area.

For this purpose, the territorial unit of analysis selected is the rural county (LAU 1). From an instrumental and practical perspective, in the case of Andalusia, the rural territory coincides with the county scope of application of the rural development programs. Andalusia has 52 rural counties, each of which is managed by a Local Action Group, covering approximately $80 \%$ of the regional territory, and bringing almost seven hundred municipalities and more than 3 million inhabitants.

\subsection{Research Methodology and Stages}

The five stages of the methodology used to achieve the main objective and the statistical methods involved in each are shown in Figure 3.

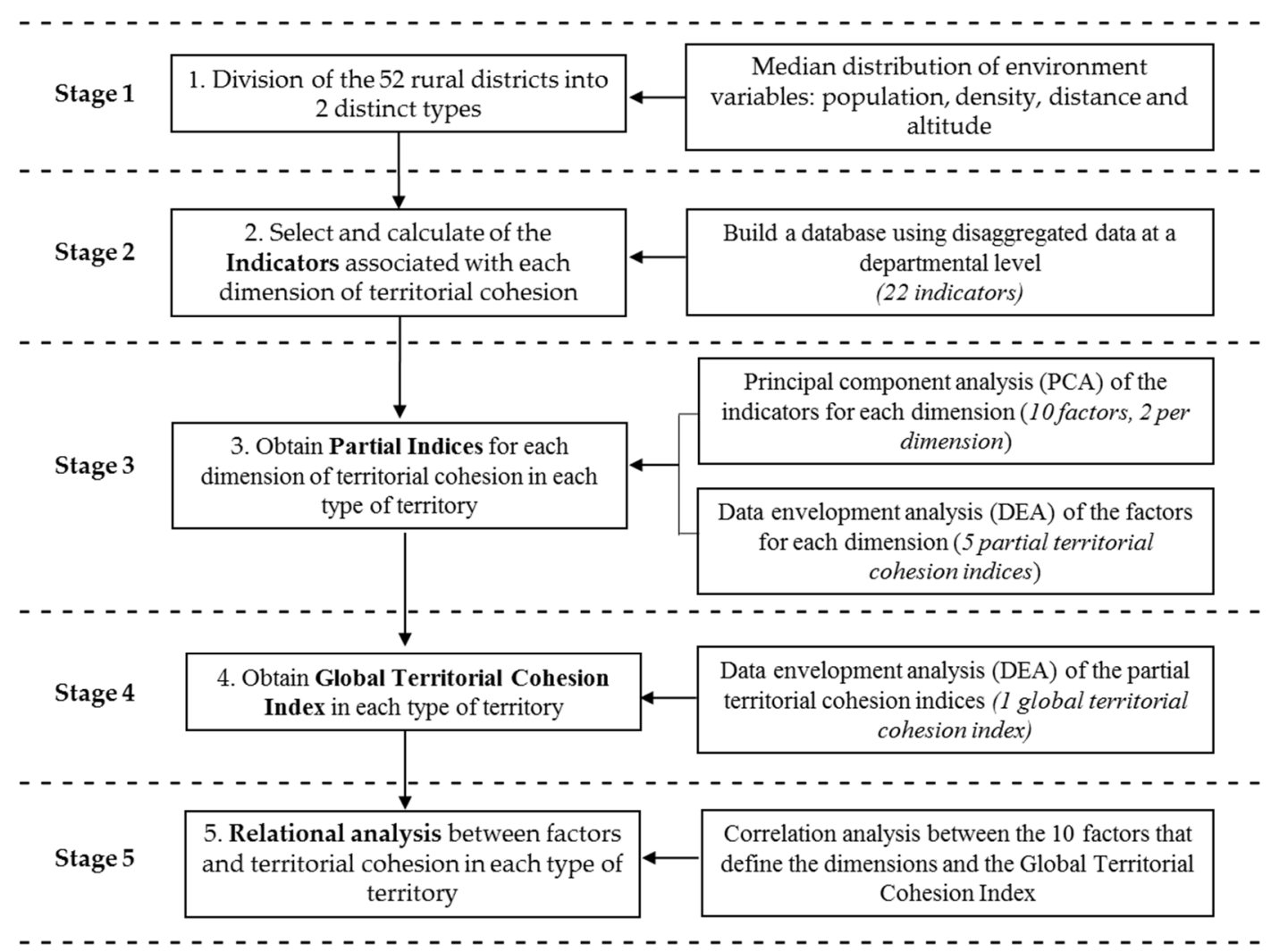

Figure 3. Research methodology. 


\subsubsection{Identifying Territorial Contexts}

The first stage of the methodology was to identify different territorial contexts for cohesion analysis. This is a fundamental stage prior to the measurement of cohesion and the identification of the factors affecting it, since, as stated in the introduction section, this type of analysis, which compares some counties with others, must be performed in territorial contexts that are more or less similar in terms of the location and the territorial resources they have. In Andalusia, at least two main types of rural environment can be identified both in terms of the position of the counties (mountainous areas as opposed to valley, fertile plain, and coastal areas) and in terms of the demographic potential they present [21].

In this sense, an analysis was performed in which the 52 rural counties were divided into two groups. This division was made on the basis of the following variables: (i) Population; (ii) population density; (iii) proximity to the main city of the NUTS 3 area; and (iv) low altitude above sea level. These are four variables that can be considered categorical variables, i.e., they can be used to establish classes or categories of environment that are favorable to the processes of rural development and territorial cohesion. These variables were condensed into a single one that has a positive connotation in terms of environment when it increases in numerical value. In order to add them, each of the four was given an equal weighting, and they were previously standardized to avoid the presence of different measurement units distorting the weighting. Finally, the two groups were formed using the median of the distribution [77].

\subsubsection{Selection of Indicators to Measure Territorial Cohesion}

Table 1 shows the variables and indicators selected to measure each of the dimensions of territorial cohesion. This selection was made on the basis of the contributions derived from the bibliographic review previously presented and the availability of the information provided by official statistical sources. There is a total of 22 indicators, expressed in the sense "the more the merrier", so that an increase in the numerical value reflects an increase in territorial cohesion. The data refer to years after the economic crisis. Depending on the indicator, the year varies between 2013 and 2017.

Table 1. Indicators of territorial cohesion for each dimension.

\begin{tabular}{|c|c|c|c|c|}
\hline Dimension & Variable & Indicator & Notation & Definition \\
\hline \multirow{5}{*}{ Economic } & Employment & Employment rate & EMPL & $\begin{array}{l}\text { Employed-to-Active population ratio } \\
\text { (100-unemployment rate) }(\%)\end{array}$ \\
\hline & Growth & $\begin{array}{l}\text { Income growth } \\
(2013-2016)\end{array}$ & INCOME & $\begin{array}{l}\text { Percentage increase in the county's } \\
\text { income }(\%)\end{array}$ \\
\hline & $\begin{array}{l}\text { Innovation and } \\
\text { investment }\end{array}$ & $\begin{array}{l}\text { Business } \\
\text { investment }\end{array}$ & INVEST & $\begin{array}{l}\text { Investment in the creation of new } \\
\text { businesses (€/pers) }\end{array}$ \\
\hline & $\begin{array}{l}\text { Economic } \\
\text { structure }\end{array}$ & $\begin{array}{l}\text { Economic } \\
\text { diversification }\end{array}$ & DIVER & $\begin{array}{l}\text { Based on the inverse of the } \\
\text { Herfindahl-Hirschman Index (HHI). } \\
\text { Data correspond to the number of } \\
\text { new business and professional } \\
\text { activities weighted by the population } \\
\text { corresponding to the primary sectors, } \\
\text { construction, industry, and services } \\
\text { (dimensionless) }\end{array}$ \\
\hline & $\begin{array}{l}\text { Economic } \\
\text { dynamism }\end{array}$ & $\begin{array}{l}\text { Economic activity } \\
\text { index }\end{array}$ & EAI & $\begin{array}{l}\text { Total number of new business and } \\
\text { professional activities weighted by } \\
\text { population (dimensionless) }\end{array}$ \\
\hline
\end{tabular}


Table 1. Cont.

\begin{tabular}{|c|c|c|c|c|}
\hline Dimension & Variable & Indicator & Notation & Definition \\
\hline \multirow{4}{*}{ Social } & $\begin{array}{l}\text { Education and } \\
\text { training }\end{array}$ & $\begin{array}{l}\text { University } \\
\text { education }\end{array}$ & UNI & $\begin{array}{l}\text { Percentage of the population with } \\
\text { university education }(\%)\end{array}$ \\
\hline & Inclusion & Gender Equality & INCLU & $\begin{array}{l}\text { Percentage of women councilors in town } \\
\text { halls in relation to the total number of } \\
\text { councilors }(\%)\end{array}$ \\
\hline & Equity & $\begin{array}{l}\text { Income } \\
\text { decentralization }\end{array}$ & EQUITY & $\begin{array}{l}\text { Based on the inverse of the } \\
\text { Herfindahl-Hirschman Index (HHI). It } \\
\text { represents similar levels of per capita } \\
\text { income among the municipalities that make } \\
\text { up the region (dimensionless) }\end{array}$ \\
\hline & Cooperatives & $\begin{array}{l}\text { Cooperative } \\
\text { networks }\end{array}$ & COOP & $\begin{array}{l}\text { Number of cooperatives per thousand total } \\
\text { population (dimensionless) }\end{array}$ \\
\hline \multirow{5}{*}{ Environment } & Climate change & $\begin{array}{l}\text { Inverse } \mathrm{CO} 2 \\
\text { emissions }\end{array}$ & $\mathrm{CC}$ & $\begin{array}{l}\text { Based on the inverse value of total CO2 } \\
\text { emissions ( } 1 / \mathrm{CO} 2 \text { emissions) (1/Mt CO2 } \\
\text { equivalent) }\end{array}$ \\
\hline & Biodiversity & Natura 2000 & NATU & $\begin{array}{l}\text { Percentage of surface area designated as } \\
\text { Special Area of Conservation (SAC) and } \\
\text { Special Protection Area (SPA) versus total } \\
\text { surface area }(\%)\end{array}$ \\
\hline & Nature & Forest surface area & FOREST & $\begin{array}{l}\text { Percentage of surface area covered by } \\
\text { natural vegetation and forests versus total } \\
\text { surface area }(\%)\end{array}$ \\
\hline & Invulnerability & $\begin{array}{l}\text { Surface area with } \\
\text { low risk of erosion }\end{array}$ & INVUL & $\begin{array}{l}\text { Percentage of surface area with erosion } \\
\text { levels classified as low or medium }(\%)\end{array}$ \\
\hline & $\begin{array}{l}\text { Availability of } \\
\text { resources }\end{array}$ & Water distribution & WATER & $\begin{array}{l}\text { Percentage of region covered by reservoirs, } \\
\text { marshland, salt flats, aquaculture, and } \\
\text { rivers, streams, and other wetlands versus } \\
\text { total surface area (\%). }\end{array}$ \\
\hline \multirow{4}{*}{ Institutional } & Participation & $\begin{array}{l}\text { Average voter } \\
\text { turnout in elections }\end{array}$ & PART & $\begin{array}{l}\text { Average percentage of votes in general, } \\
\text { regional, and local elections per total } \\
\text { voters }(\%)\end{array}$ \\
\hline & Investment & $\begin{array}{l}\text { Expenditure vs. } \\
\text { Income per capita }\end{array}$ & EXPEN & $\begin{array}{l}\text { Percentage of expenditure per capita versus } \\
\text { income per capita }(\%)\end{array}$ \\
\hline & Partnership & $\begin{array}{l}\text { Private sector } \\
\text { participation }\end{array}$ & PRIV & $\begin{array}{l}\text { Percentage of private members and } \\
\text { businesses on the board of directors of } \\
\text { Rural Development Groups (\%) }\end{array}$ \\
\hline & Associations & $\begin{array}{l}\text { Association } \\
\text { networks }\end{array}$ & ASSOC & $\begin{array}{l}\text { Number of sector and business associations, } \\
\text { cooperatives, and civic associations in the } \\
\text { overall structure of Rural Development } \\
\text { Group }(\%)\end{array}$ \\
\hline \multirow{4}{*}{$\begin{array}{l}\text { Integrated } \\
\text { spatial } \\
\text { development }\end{array}$} & Density & Population density & DENS & Population per square kilometer (pers/km2). \\
\hline & Flows & $\begin{array}{l}\text { Population increase } \\
\text { (2012-2016) }\end{array}$ & FLOW & $\begin{array}{l}\text { Rate of change in population, expressed as } \\
\text { a percentage, in the period } 2012-2016(\%)\end{array}$ \\
\hline & Connectivity & $\begin{array}{l}\text { Internet } \\
\text { penetration }\end{array}$ & ADSL & $\begin{array}{l}\text { Number of ADSL per thousand inhabitants } \\
\text { (dimensionless) }\end{array}$ \\
\hline & Connection & Road network & ROAD & $\begin{array}{l}\text { Proportion of surface area of motorway, } \\
\text { freeways, and road links in relation to total } \\
\text { regional surface area (\%) }\end{array}$ \\
\hline
\end{tabular}

\subsubsection{Obtaining Partial Indices in Each Type of Territory}

In order to obtain the five partial indexes of territorial cohesion (one for each dimension), two fundamental steps were followed. Both were applied independently in each of the two groups of territories previously identified. Firstly, a factorial analysis (principal components method and varimax 
orthogonal rotation) was conducted with the indicators included in each of the five dimensions, and then the resulting factors in each of these were grouped together to form the five synthetic indices. The aggregation of these factors was undertaken using the Data Envelopment Analysis (DEA) technique. The suitability of the use of this technique lies mainly in the fact that it allows the weighting of the factors to be obtained through an objective and endogenous calculation, in a way that is neither arbitrary nor based on personal opinion.

DEA is originally a non-parametric procedure that uses a linear programming technique to evaluate the relative efficiency of a set of production or decision units. To this end, it compares the behavior of this set of units through their capacity to transform inputs into outputs, taking as a reference a frontier constituted by the best production practices observed in that set (for a more in-depth analysis of the mathematical development of the model underlying this technique, see the original work by Charnes et al. [78]).

In recent years, other applications of the DEA technique have been developed, including its usefulness in the elaboration of synthetic indices from partial indicators. Among the studies that have made this specific use of DEA, those performed in the field of sustainability $[79,80]$, quality of life, welfare and human development [81-84], and territorial analysis $[20,21,77,85]$ are highlighted. The model proposed below is based on this literature.

Our objective is the construction of a composite index associated with each county from a set of factors corresponding to different facets of territorial cohesion. To this end and under the multi-criteria decision analysis approach, DEA analysis can be assimilated to a function that aggregates output and inputs into a single value measure [86,87]. Assuming a single input for each county analyzed and making it equal to the unit, the following model is proposed:

$$
\operatorname{Max}_{\mu_{r o}} h_{0}=\sum_{r=1}^{R} \mu_{r o} I_{r o}
$$

Subject to:

$$
\begin{gathered}
\sum_{r=1}^{R} \mu_{r o} I_{r k} \leq 1 \quad k=1, \ldots, K \\
\mu_{r o} \geq 0 \quad r=1, \ldots, R
\end{gathered}
$$

where $h_{0}$ is territorial cohesion (in the corresponding dimension) of the county analyzed; $\mu_{r o}$ is the weight of indicator/factor $r$, the most favorable for the attributes of the county; and $I_{r k}$ represents the value of indicator/factor $r$.

It is therefore a question of maximizing the weighted sum of certain characteristics or attributes that favor territorial cohesion (maximization of a set of indicators or factors, $I$ ). It operates with a virtual input equal to the unit for all of the counties (first set of restrictions). The weightings are those that are most favorable for the attributes of the region being analyzed.

At this stage, this DEA model was applied five times, once for each dimension of territorial cohesion, to obtain the five partial indices. This makes it possible to rank the counties according to their levels of relative performance in each of the dimensions. Specifically, the model that was applied is a CCR (named for Charnes, Cooper and Rhodes who initially proposed the model in 1978) focused on outputs and with a virtual input equal to the unit, and the software used for the calculations was the Banxia Frontier Analyst.

\subsubsection{Obtaining the Global Territorial Cohesion Index in Each Type of Territory}

The elaboration of the global territorial cohesion index (GTCI) associated with each county was performed by adding the five partial indexes obtained in the previous phase. This aggregation was undertaken using the DEA model developed in the previous phase. This made it possible to rank 
rural counties according to their overall levels of territorial cohesion. This process was conducted independently in each set of counties belonging to the two groups of territories previously identified.

\subsubsection{Identifying the Factors Associated with Territorial Cohesion for Each Type of Territory}

Lastly, once the territorial cohesion indices of each of the counties were estimated, the next step was to identify the factors that might be associated with territorial cohesion in each type of rural territory. To this end, a correlation analysis (Spearman coefficient) was performed between the factors that define the different dimensions contemplated and the GTCI.

\section{Results and Discussion}

The identification of different territorial contexts for analyzing territorial cohesion made it possible to establish two groups or categories of rural counties with environments that are more or less favorable to the processes of rural development and territorial cohesion (Figure 4).

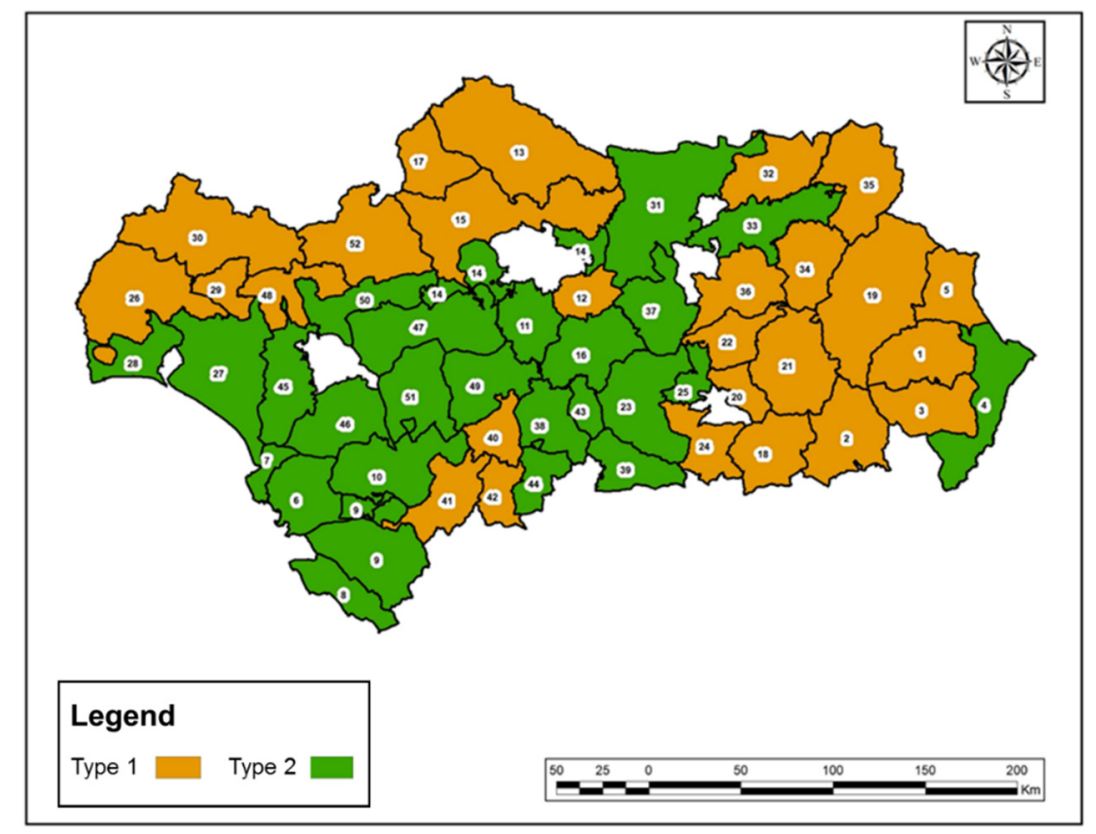

Figure 4. Types of rural territory.

Based on the main characteristics of the counties, two groups or types of rural territories can be found:

- $\quad$ Type 1 covers remote peripheral areas, generally located in mountainous areas with significant demographic and educational problems. They have a valuable natural heritage and an agricultural and livestock sector with an important weight in the rural economy of the counties. These are the rural areas which, a priori, present the least favorable environments for progressing in their development and territorial cohesion.

- Type 2 includes counties with favorable orography and geographical location, in some cases near the main cities of the counties and, in others, with good communication with the main centers of development in the region. They have great demographic potential and, in addition to an important agricultural and agri-food sector, the industrial and service sectors stand out.

The application of the factor analysis performed independently in each of the two types of rural territories for each of the dimensions of territorial cohesion allowed the original 22 indicators to be reduced to a total of 10 factors in each of the types (two for each dimension) (Table 2). The results of the factor analyses are summarized in Appendix A (Tables A1 and A2). 
Table 2. Factors linked to the dimensions of territorial cohesion.

\begin{tabular}{|c|c|}
\hline Type 1 & Type 2 \\
\hline \multicolumn{2}{|c|}{ Economic dimension } \\
\hline F1. Economic growth, employment, and innovation & $\begin{array}{l}\text { F1. Economic growth, diversification, } \\
\text { and employment }\end{array}$ \\
\hline F2. Economic activity and diversification & $\begin{array}{l}\text { F2. Entrepreneurship, innovation, and economic } \\
\text { activity }\end{array}$ \\
\hline \multicolumn{2}{|c|}{ Social dimension } \\
\hline F3. Training and gender equality & F3. Training and territorial equity \\
\hline F4. Cooperatives and territorial equity & F4. Cooperatives and gender equality \\
\hline \multicolumn{2}{|c|}{ Environmental dimension } \\
\hline F5. Resource availability and environmental quality & F5. Resource availability and environmental quality \\
\hline F6. Biodiversity, forests, and natural areas & F6. Biodiversity, forests, and natural areas \\
\hline \multicolumn{2}{|c|}{ Institutional dimension } \\
\hline F7. Public expenditure and citizen participation & F7. Public expenditure and citizen participation \\
\hline F8. Private initiative and territorial governance & F8. Private initiative and territorial governance \\
\hline \multicolumn{2}{|c|}{ Integrated spatial development dimension } \\
\hline F9. Density, flows, and internet access & F9. Density and flow \\
\hline F10. Road network and communication & $\begin{array}{l}\text { F10. Road network, communication, } \\
\text { and internet access }\end{array}$ \\
\hline
\end{tabular}

A partial territorial cohesion index (PTCI) relating to each dimension was obtained by applying the DEA based on the resulting factors. The GTCI was also obtained by aggregating indices using the DEA. Tables 3 and 4 summarize the results obtained in each analysis for the counties of each type of territory.

Table 3. Partial and global territorial cohesion indices for type 1 counties.

\begin{tabular}{|c|c|c|c|c|c|c|c|}
\hline No. & Counties & PTCI_Eco & PTCI_Soc & PTCI_Env & PTCI_Inst & PTCI_Space & GTCI \\
\hline 1 & Almanzora & 88.22 & 25 & 41.07 & 71 & 36 & 76.64 \\
\hline 2 & Alpujarra-Sierra Nevada Almeriense & 100 & 29 & 75.56 & 81 & 65.87 & 100 \\
\hline 3 & Filabres Alhamilla & 99.44 & 34.03 & 65.37 & 85 & 41.44 & 93.79 \\
\hline 5 & Los Vélez & 98.79 & 100 & 38.78 & 52 & 55.32 & 100 \\
\hline 12 & Guadajoz y Campiña Este & 71.86 & 100 & 3 & 97 & 61.6 & 100 \\
\hline 13 & Los Pedroches & 100 & 46.88 & 51.5 & 98 & 34 & 100 \\
\hline 15 & Sierra Morena Cordobesa & 50.42 & 73 & 75.33 & 77.42 & 36 & 85.25 \\
\hline 17 & Valle del Alto Guadiato & 33 & 54 & 43.07 & 75 & 37 & 60.19 \\
\hline 18 & Alpujarra-Sierra Nevada de Granada & 37.51 & 39 & 65.3 & 49 & 51 & 61.43 \\
\hline 19 & Altiplano de Granada & 77.08 & 47.81 & 40.18 & 72 & 24.98 & 72.39 \\
\hline 20 & Arco Noroeste de la Vega de Granada & 46.72 & 94 & 77 & 100 & 100 & 100 \\
\hline 21 & Guadix & 75.21 & 38 & 46.6 & 79.26 & 76.62 & 81.02 \\
\hline 22 & Montes de Granada & 82.28 & 77 & 24 & 100 & 100 & 100 \\
\hline 24 & Valle Lecrin Temple Costa & 65.39 & 66 & 39.74 & 88 & 72.48 & 80.1 \\
\hline 26 & Andévalo Occidental & 37.24 & 45 & 113 & 15 & 43 & 96 \\
\hline 29 & Cuenca minera de Riotinto & 3 & 67.12 & 62 & 49 & 52 & 70.7 \\
\hline 30 & Sierra de Aracena y Picos de Aroche & 58 & 56 & 100 & 92 & 50 & 100 \\
\hline 32 & Condado de Jaén & 45.5 & 55.23 & 59.1 & 78.11 & 38 & 70.05 \\
\hline 34 & Sierra de Cazorla & 65.44 & 65.91 & 66 & 97 & 36 & 90.06 \\
\hline 35 & Sierra de Segura & 78.59 & 48 & 100 & 77.42 & 26 & 100 \\
\hline 36 & Sierra Mágina & 53.11 & 80 & 37 & 93 & 68.05 & 81.08 \\
\hline 40 & Guadalteba & 100 & 74 & 26.61 & 46.08 & 55 & 100 \\
\hline 41 & Serranía de Ronda & 51.5 & 75 & 81 & 26 & 44 & 90.15 \\
\hline 42 & Sierra de las Nieves & 71.67 & 90 & 70.15 & 62 & 49 & 98.91 \\
\hline 48 & Corredor de la Plata & 38 & 77 & 61.16 & 47 & 75 & 76.9 \\
\hline 52 & Sierra Morena Sevillana & 41.15 & 48.65 & 92.54 & 33 & 41 & 79 \\
\hline
\end{tabular}


Table 4. Partial and global territorial cohesion indices for type 2 counties.

\begin{tabular}{|c|c|c|c|c|c|c|c|}
\hline No. & Counties & PTCI_Eco & PTCI_Soc & PTCI_Env & PTCI_Inst & PTCI_Space & GTCI \\
\hline 4 & Levante Almeriense & 100 & 26 & 82.45 & 70.58 & 77 & 100 \\
\hline 6 & Campiña de Jerez & 71 & 100 & 76.65 & 86.09 & 88.22 & 100 \\
\hline 7 & Costa Noroeste de Cádiz & 19 & 69.45 & 79 & 100 & 100 & 100 \\
\hline 8 & Litoral de la Janda & 52 & 60 & 61.55 & 96.27 & 61 & 84.21 \\
\hline 9 & Los Alcornocales & 31.82 & 83.53 & 100 & 30.7 & 67 & 94 \\
\hline 10 & Sierra de Cádiz & 53 & 35.92 & 44 & 76.05 & 33.26 & 55.7 \\
\hline 11 & Campiña Sur de Córdoba & 84.16 & 70.61 & 47 & 83.16 & 53.56 & 80.52 \\
\hline 14 & Medio Guadalquivir & 100 & 39.45 & 64.72 & 88.83 & 42 & 92.38 \\
\hline 16 & Subbética Cordobesa & 76.49 & 53.74 & 35.85 & 98.39 & 33.35 & 78.24 \\
\hline 23 & Poniente Granadino & 87 & 89.89 & 45.68 & 100 & 36 & 100 \\
\hline 25 & Vega Sierra-Elvira & 47.57 & 100 & 46 & 62.42 & 100 & 100 \\
\hline 27 & Condado de Huelva & 45.59 & 100 & 93.81 & 84.32 & 53.44 & 100 \\
\hline 28 & Costa Occidental de Huelva & 32.87 & 100 & 100 & 59.88 & 71 & 100 \\
\hline 31 & Campiña Norte de Jaén & 60.68 & 86.2 & 62.84 & 79 & 38 & 79.38 \\
\hline 33 & La Loma y las Villas & 67.9 & 66.04 & 30.61 & 84 & 37 & 66.19 \\
\hline 37 & Sierra Sur de Jaén & 89.44 & 72.52 & 23.23 & 68 & 24.16 & 84.04 \\
\hline 38 & Antequera & 84.58 & 84.4 & 45.26 & 36 & 48 & 91.92 \\
\hline 39 & Axarquía & 66.19 & 61.56 & 34 & 79.34 & 55.12 & 67.9 \\
\hline 43 & Territorio Nororiental de Málaga & 96.66 & 86 & 31.56 & 41 & 49 & 100 \\
\hline 44 & Valle del Guadalhorce & 63 & 60.75 & 27.35 & 38.69 & 58.63 & 63.24 \\
\hline 45 & Aljarafe-Doñana & 39.13 & 93.17 & 100 & 75.16 & 57 & 100 \\
\hline 46 & Bajo Guadalquivir & 24.24 & 98.56 & 56 & 94.77 & 59.17 & 96.26 \\
\hline 47 & Campiña y los Alcores de Sevilla & 59.51 & 92.04 & 59 & 71 & 49.59 & 83.01 \\
\hline 49 & Estepa Sierra Sur Sevilla & 100 & 68 & 49 & 100 & 41 & 100 \\
\hline 50 & Gran Vega de Sevilla & 35.12 & 81.15 & 52.22 & 67 & 62.83 & 68.19 \\
\hline 51 & Serranía Suroeste Sevillana & 62 & 65.41 & 31.19 & 74.96 & 38 & 61.26 \\
\hline
\end{tabular}

The results for the economic dimension (PTCI_Eco) show that three type 1 counties ('Alpujarra Sierra Nevada Almeriense', 'Los Pedroches', and 'Gudalteba') and three type 2 counties ('Levante Almeriense', 'Medio Guadalquivir', and 'Estepa Sierra Sur Sevillana') are the most favorable or efficient (with indices equal to one hundred). In the case of the type 1 counties, 'Alpujarra Sierra Nevada de Almería' stands out from the rest due to factors such as innovation and the level of entrepreneurship, which has earned it recognition in past editions by the Andalusian Center for Entrepreneurship. 'Guadalteba' and, above all, 'Los Pedroches' stand out for the dynamism and diversification of their economies, closely linked to the agricultural and livestock sector. In the type 2 counties, 'Levante Almeriense' stands out mainly for its economic dynamism, closely linked to horticulture and the agri-food sector and its high level of employment; the 'Medio Guadalquivir' county for the levels of investment in the creation of new industries; and 'Estepa Sierra Sur' for the diversification of its economy and the high levels of economic growth experienced in recent years.

The results obtained for the social dimension partial indices (PTCI_Soc) show that, in type 1, there are two counties that show the most favorable situation ('Los Vélez' and 'Guadajoz y Campiña Este'), and there are four counties that can be observed in type 2 ('Campiña de Jerez', 'Vega Sierra Elvira', 'Condado de Huelva', and 'Costa Occidental de Huelva'). In the case of the type 1 counties, 'Los Vélez' stands out from the rest because of the equitable distribution of income among the municipalities that make up the county, and 'Guadajoz and Campiña' Este because of the high rates of representation of women in decision-making positions. In the case of type 2 regions, 'Campiña de Jerez' stands out for its high levels of decentralization of income and territorial equity, 'Vega Sierra Elvira' for the high levels of training of the population, 'Condado de Huelva' for cooperative promotion, and 'Costa Occidental de Huelva' for inclusion and gender equality.

The results for the environmental dimension (PTCI_Env) show that two type 1 counties ('Sierra de Aracena and Picos de Aroche' and 'Sierra de Segura') and three type 2 counties ('Los Alcornocales', 'Aljarafe Doñana', and 'Costa Occidental de Huelva') present the most favorable situation. In all cases, these are regions with a high availability of natural resources, forest areas, and Protected Natural Parks.

The results obtained for the institutional dimension (PTCI_Inst) show that two type 1 regions ('Arco Noroeste de la Vega de Granada' and 'Montes de Granada') and three type 2 counties ('Costa Noroeste de Cádiz', 'Poniente Granadino', and 'Estepa Sierra Sur') are the best positioned. 
In the case of the type 1 counties, 'Arco Noroeste de la Vega de Granada' stands out from the rest because of the high investment made by institutions in public services, and 'Montes de Granada' because of the involvement of the private sector in the development of the county. In the case of type 2 counties, 'Costa Noroeste de Cádiz' also stands out for the involvement of the private sector, 'Poniente Granadino' for the high levels of public spending per inhabitant, and 'Estepa Sierra Sur' for the degree of civil, sectoral, and business associationism.

The results for the integrated spatial development dimension (PTCI_Space) show that two type 1 counties ('Arco Noroeste de la Vega de Granada' and 'Montes de Granada') and two type 2 counties ('Costa Noroeste de Cádiz' and 'Vega Sierra Elvira') have the most favorable position. In type 1, 'Arco Noroeste de la Vega de Granada' stands out mainly because of the increase in population flow in recent years and the high penetration of internet into the county's households, while 'Montes de Granada' does so mainly because of the road connections through highways, motorways, and road links. In type 2, 'Costa Noroeste de Cádiz' stands out from the rest because of its population density, and 'Vega Sierra Elvira' because of its high per capita levels of internet access and its good road connections with the main city of the NUTS3 area.

The results obtained for the GTCI) show that nine type 1 and ten type 2 counties present the most favorable situation (those with indices equal to 100). These counties, the type of territory to which they belong, and their geographical locations are shown in Figure 5.

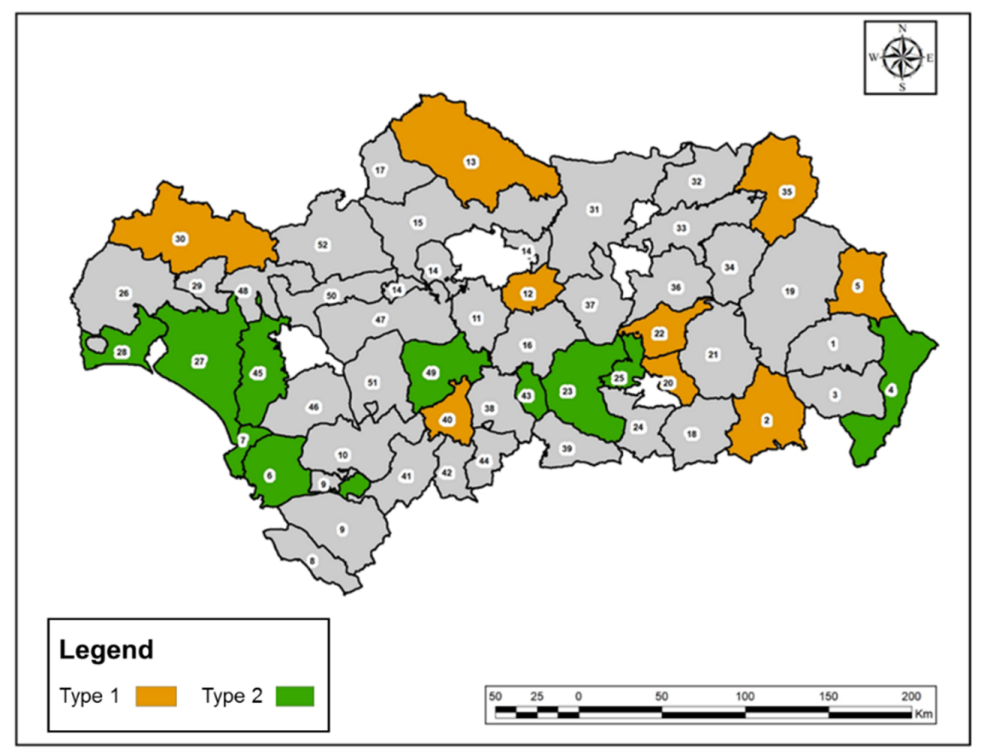

Figure 5. Location of the regions with the highest GTCI.

Among this group of regions with an index equal to 100, "Arco Noroeste de la Vega de Granada" in type 1 and "Estepa Sierra Sur" in type 2 are the ones that are most often repeated as a reference for the counties that still have the capacity to improve. Knowing the set of counties that in each type of territory act as a reference for those that are not at the optimum level can be useful in identifying the factors and dimensions in which adjustments must be made to advance the processes of cohesion.

In coherence with the phases of the methodology, Tables 5 and 6 present the results of the cohesion analyses performed in each type of territory between the factors and the global index of territorial cohesion.

In the case of type 1 counties, of the ten factors considered in the analysis, two of them are significantly and positively correlated with the global index of territorial cohesion. In both cases, these are factors related to the economic dimension. Thus, the results show that, in this type of peripheral and remote territory with significant demographic problems, those counties that have experienced the greatest economic growth, with high employment rates and economic dynamism and diversification, are those that acquire the highest level of territorial cohesion. 
Table 5. Correlation indices in type 1 territories.

\begin{tabular}{|c|c|c|}
\hline \multirow{3}{*}{ Factors } & \multicolumn{2}{|c|}{ GTCI } \\
\hline & \multicolumn{2}{|c|}{ Coefficients } \\
\hline & Pearson & Spearman \\
\hline F1. Economic growth, employment, and innovation & $0.423(*)$ & $0.350\left(^{*}\right)$ \\
\hline F2. Economic activity and diversification & $0.374\left(^{*}\right)$ & $\left.0.349{ }^{*}{ }^{*}\right)$ \\
\hline F3. Training and gender equality & 0.241 & 0.232 \\
\hline F4. Cooperatives and territorial equity & 0.128 & 0.074 \\
\hline F5. Resource availability and environmental quality & -0.136 & -0.27 \\
\hline F6. Biodiversity, forests, and natural areas & 0.164 & 0.127 \\
\hline F7. Public expenditure and citizen participation & 0.112 & 0.185 \\
\hline F8. Private initiative and territorial governance & 0.112 & 0.15 \\
\hline F9. Density, flows, and internet access & -0.13 & -0.141 \\
\hline F10. Road network and communication & 0.282 & 0.228 \\
\hline
\end{tabular}

* The correlation is significant at the 0.05 level (two-tailed).

Table 6. Correlation indices in type 2 territories.

\begin{tabular}{lrr}
\hline & \multicolumn{1}{c}{ GTCI } \\
& \multicolumn{1}{c}{ Coefficients } \\
\cline { 2 - 3 } & \multicolumn{1}{c}{ Spearsonan } \\
\hline F1. Economic growth, diversification, and employment & -0.126 & -0.145 \\
F2. Entrepreneurship, innovation, and economic activity & 0.257 & 0.176 \\
F3. Training and territorial equity & 0.123 & 0.086 \\
F4. Cooperatives and gender equality & 0.18 & 0.255 \\
F5. Resource availability and environmental quality & 0.198 & 0.17 \\
F6. Biodiversity, forests, and natural areas & $0.609\left(^{* *}\right)$ & $0.597\left(^{* *}\right)$ \\
F7. Public expenditure and citizen participation & -0.141 & -0.189 \\
F8. Private initiative and territorial governance & 0.137 & 0.194 \\
F9. Density and flow & 0.123 & 0.127 \\
F10. Road network, communication, and internet access & $0.414\left(^{*}\right)$ & $0.418\left(^{*}\right)$ \\
\hline ** The correlation is significant at the 0.01 level (two-tailed). ${ }^{*}$ The correlation is significant at the 0.05 level
\end{tabular}

These results are in line with those obtained in other research conducted in the same geographical area as the one analyzed in this research $[20,21,85]$. These studies show that the diversification of the economy is a decisive factor for the resilience, development, and cohesion of rural territories. Additionally, other studies that focused on another Spanish region [69] and on the European regional level [88,89] highlight that diversification, innovation, and entrepreneurship act as drivers that contribute to the development of territories and regions.

In the case of type 2 counties, of the ten factors considered in the analysis, two of them are also significantly and positively correlated with the global index of territorial cohesion. One relates to the environmental dimension and the other to the integrated spatial development dimension. Thus, the results show that, in this type of territory with a more favorable geographical situation and demographic potential, those counties with quality environmental resources and connection infrastructures, both road and internet access, are those with the highest levels of territorial cohesion.

Factors relating to the availability of natural resources, the presence of forest areas, or high levels of biodiversity have also been previously identified as drivers of development in rural Andalusia [20,21] and in other European [90] and North American [91] areas. Similarly, factors associated with the accessibility and connectivity of rural territories and investment in transport infrastructure have proved to be decisive for the cohesion of rural territories in Andalusia [21] and northern Spain [92] 


\section{Conclusions}

This research has made progress in the conceptualization of territorial cohesion, but, above all, in the design of a methodological proposal that allows an empirical approach to be taken to its evaluation and measurement, as well as to the analysis of the factors that affect it. To analyze the applicability and operability of this methodological proposal, the research was developed in the rural milieu of the region of Andalusia.

In this regard, it is important to note that the difficulty of a methodological approach to a concept that is still somewhat diffuse is compounded by others of an instrumental and practical nature, since studies of territorial cohesion at the regional level face a twofold problem: (i) Identifying smaller territorial units on which to perform analyses, and (ii) finding in those units the information needed to address them. Regarding the first problem, the two smaller units with administrative entities in Spain are the province (NUTS3) and the municipality (LAU2). However, neither of them is recommended for the analysis of territorial cohesion, since, in the first case, the internal heterogeneity of the unit is very high and includes both rural and urban areas, and the second case is too disaggregated for territorial studies. Consequently, it is necessary to identify intermediate territorial units that serve the purposes of territorial cohesion analysis. In the rural area, the units that have autonomy at that level for planning and promoting their development are the rural counties. However, in relation to the second problem previously mentioned, it is important to highlight that there is information that could further enrich the empirical analysis, but this is not disaggregated at the county or municipal level, which limits the possibilities of the study.

However, despite these difficulties, the proposed methodology has a number of features that make it practically useful and applicable in this and any other geographical area: (i) It is based on an extensive bibliographical review of both scientific literature and documents derived from the work of the main European institutions; (ii) it presents an integrated and holistic vision of the concept of territorial cohesion and the different dimensions that make it up; (iii) it simplifies the complexity of the concept and makes it operational and measurable; (iv) measurement is based on a careful selection of indicators and is performed in stages through the aggregation of elements facilitating the understanding of the analysis. In any case, it should be remembered that the methodological tools used to measure territorial cohesion only provide relative-not absolute-results, given that rural counties are classified and hierarchized by making comparisons between them.

This is a consistent methodology with significant potential in a context where data availability will tend to be increasingly immediate, thus ensuring the automation of monitoring in the evolution of indicators. Monitoring could contribute to improved decision-making by policymakers, leading to better design and implementation of interventions, assistance for more efficient resource allocation, and quality and transparency of achievements.

The results derived from the application of the methodology reveal some elements that promote processes of territorial cohesion in rural Andalusia. Specifically, in type 1 territories, the cohesion and development of their counties should be based on the diversification of the sources of income of the local population, taking advantage of the various opportunities offered by their natural and cultural heritage. This diversification should be based on innovation and entrepreneurship, including in the agricultural sector and the food industry, boosting local production activities, and seeking new value chains.

In type 2 territories, the challenge for cohesion is to understand that both rural and urban areas are part of the same territory. It is therefore necessary to intensify relations and connections between the two, making available to economic and social actors the appropriate resources and road infrastructure to make this interaction possible. Territorial planning, approached in an integrated and sustainable manner, which also takes into account the value of natural areas, should play a key role in avoiding the risk of imbalances in urban-rural relations in these areas.

In this respect, it can be concluded that high levels of economic growth, employment, innovation, and diversification of the economy, as well as the availability of both natural resources that provide 
environmental quality and infrastructure for road connections and internet access, are factors that contribute to the cohesion of Andalusian rural territories.

The results obtained also show that the relationship between these factors and the processes of territorial cohesion depends on the type of territory and its characteristics. These results highlight two important conclusions that should be taken into account because of their implication for the design of public policies: (i) Policies should incorporate in their proposals instruments that enable the promotion and activation of the specific factors that contribute to territorial cohesion, and (ii) a different territorial reality requires flexible policies that enable the correct use of the principle of subsidiarity. This flexibility implies objectives and measures adapted to different realities and prioritized in different ways in order to allow territories to move forward by acting on the problems that affect them and by relying on the factors on which they can base their development.

Finally, it is important to note that when territorial cohesion is understood as a path towards the reduction of disparities within the territory under analysis, a trend and dynamic analysis is required. Therefore, future research is required in which the proposed methodology is applied over a period of time to assess territorial trends (of cohesion or exclusion) in the rural areas of Andalusia.

Author Contributions: Conceptualization, P.S.-Z. and R.G.-C.; methodology, P.S.-Z. and R.G.-C.; software, P.S.-Z.; validation, P.S.-Z. and R.G.-C.; formal analysis P.S.-Z.; resources, P.S.-Z. and R.G.-C.; writing-original draft preparation, P.S.-Z. and R.G.-C.; writing-review and editing, P.S.-Z. and R.G.-C. All authors have read and agreed to the published version of the manuscript.

Funding: This research has been developed in the context of the "El medio rural andaluz frente a la crisis económica: dinámicas territoriales, factores de resiliencia y estrategias de adaptación" project (Ref: 150/17) funded by the Fundación Pública Andaluza Centro de Estudios Andaluces (X Call for Research Projects 2017).

Conflicts of Interest: The authors declare no conflicts of interest.

\section{Appendix A}

Table A1. Results of the factor analyses for type 1 counties.

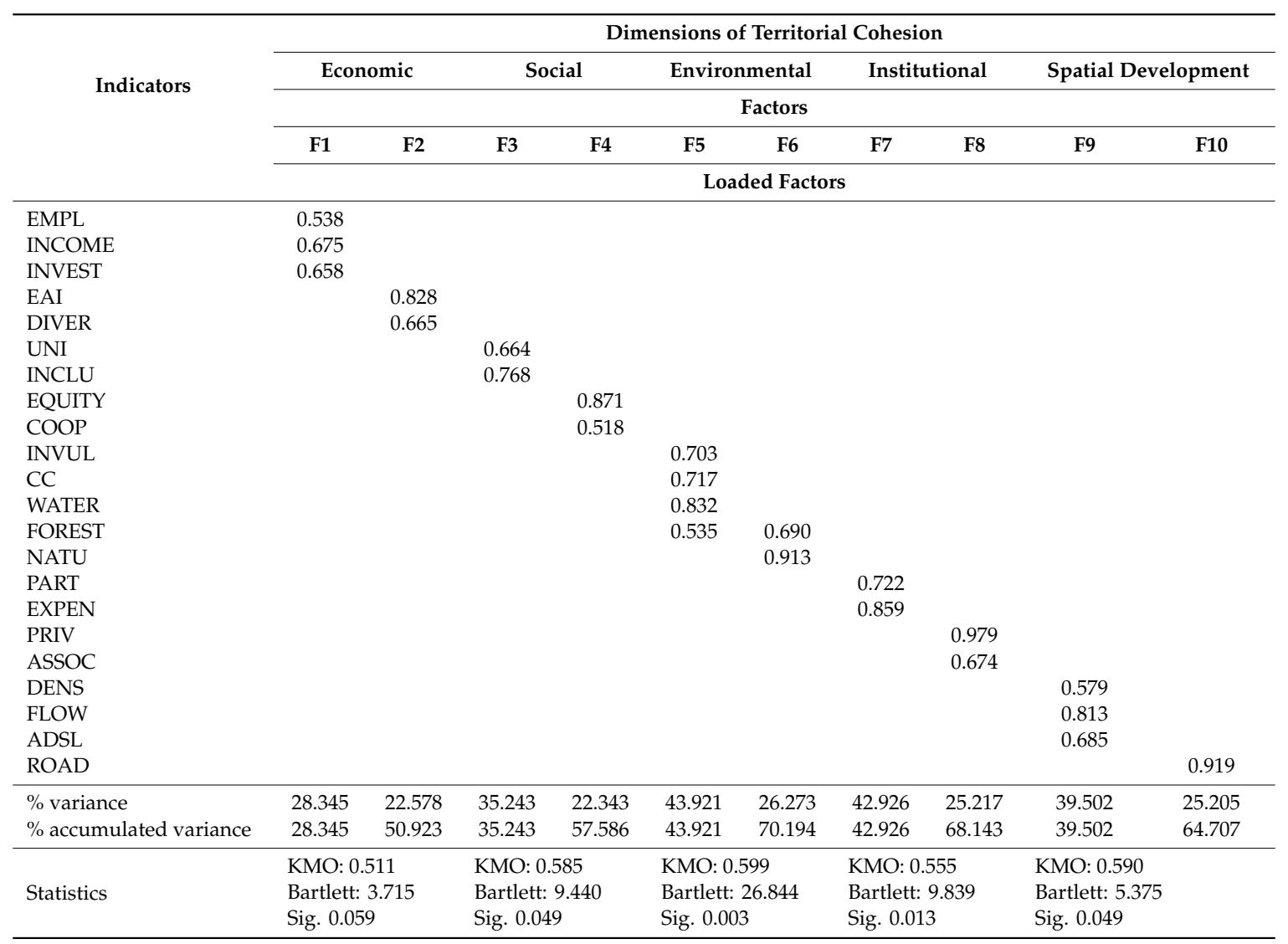


13. Dunford, M.; Perron, D. Regional inequality, regimes of accumulation and economic development in contemporary Europe. Trans. Inst. Br. Geogr. 1994, 19, 163-182. [CrossRef]

14. Evans, P.; McCormic, B. The new pattern of regional unemployment: Causes and policy significance. Econ. J. 1994, 104, 633-647. [CrossRef]

15. Dunford, M.; Smith, A. Catching up or falling behind? Economic performance and regional trajectories in the "New Europe". Econ. Geogr. 2009, 76, 169-195. [CrossRef]

16. Capello, R.; Caragliu, A.; Fratesi, U. Spatial heterogeneity in the costs of the economic crisis in Europe: Are cities sources of regional resilience? J. Econ. Geogr. 2015, 15, 951-972. [CrossRef]

17. Copus, A.K.; Well, L. Parallel worlds? Comparing the perspectives and rationales of EU rural development and cohesion policy. In Territorial Cohesion in Rural Europe-The Relational Turn in Rural Development; Copus, A.K., Lima, P., Eds.; Taylor \& Francis Book: Abingdon, UK, 2014; ISBN 978-0-415-85950-9.

18. Pelucha, M.; Kveton, V.; Safr, K. Theory and reality of the EU's rural development policy application in the context of territorial cohesion perspective-The case of the Czech Republic in the long-term period of 2004-2013. Land Use Pol. 2017, 62, 13-28. [CrossRef]

19. Saraceno, E. Disparity and diversity: Their use in EU rural policies. Sociol. Rural. 2013, 53, 331-348. [CrossRef]

20. Sánchez-Zamora, P.; Gallardo-Cobos, R.; Ceña-Delgado, F. Rural areas face the economic crisis: Analyzing the determinants of successful territorial dynamics. J. Rural Stud. 2014, 35, 11-25. [CrossRef]

21. Sánchez-Zamora, P.; Gallardo-Conos, R. Diversity, disparity and territorial resilience in the context of the economic crisis: An analysis of rural areas in southern Spain. Sustainability 2019, 11, 1743. [CrossRef]

22. Stewart, F. Horizontal inequalities: A Neglected Dimension of Development; United Nations University World Institute for Development Economics Research: Helsinki, Finland, 2001.

23. Sánchez-Zamora, P.; Gallardo-Cobos, R.; Romero-Huertas, C. Assessing the determinants of territorial cohesion: Evidence from Colombian departments. Geoforum 2017, 87, 48-61. [CrossRef]

24. European Commission. Second Report on Economic and Social Cohesion; Report from the Commission to the Council, the European Parliament, the Economic and Social Committee and the Committee of the Regions; European Commission: Brussels, Belgium, 2001.

25. European Commission. Green Paper on Territorial Cohesion. Turning Territorial Diversity into Strength; Communication from the Commission to the Council, the European Parliament, the Committee of the Regions and the European Economic and Social Committee; European Commission: Brussels, Belgium, 2008.

26. Evers, D. A solution in search of a problem: A 'Garbage can' approach to the politics of territorial cohesion. Eur. J. Spat. Dev. 2012, 45, 1-24.

27. Rauhut, D.; Ludlow, D. Services of general interest and territorial cohesion: What, how and by whom? Rom. J. Reg. Sci. 2013, 7, 108-123.

28. Colomb, C.; Santinha, G. European Union competition policy and the European territorial cohesion agenda: An impossible Reconciliation? State aid rules and public service liberalization through the European spatial planning lens. Eur. Plan. Stud. 2014, 22, 459-480. [CrossRef]

29. Clifton, J.; Díaz-Fuentes, D.; Fernández, M. Public infrastructure services in the European Union: Challenges for territorial cohesion. Reg. Stud. 2016, 50, 358-373. [CrossRef]

30. Nosek, S. Territorial cohesion storylines in 2014-2020 cohesion policy. Eur. Plan. Stud. 2017, 12, $2157-2174$. [CrossRef]

31. Faludi, A. Territory: An unknown quantity in debates on territorial cohesion. Eur. J. Spat. Dev. 2013, 51, 1-16.

32. Zaucha, J.; Böhme, K. Measuring territorial cohesion is not a mission impossible. Eur. Plan. Stud. 2019, 28, 627-649. [CrossRef]

33. Grasland, C.; Hamez, G. Vers la construction d'un indicateur de cohésion territorial européen? L'espace Géographique 2005, 34, 97-116. [CrossRef]

34. Medeiros, E. Territorial Cohesion: A Conceptual Analysis. In Regional Studies Conference. 2011. Available online: http://www.regionalstudies.org/uploads/funding/conferences/presentations/european-conference2012/presentations/medeiros.pdf (accessed on 6 November 2017).

35. Medeiros, E. Territorial cohesion: An EU concept. Eur. J. Spat. Dev. 2016, 60, 1-30.

36. Fernández-Tabales, A.; Pedregal-Mateos, B.; Rodríguez-Mateos, J.C.; Pita-López, M.F.; Zoido-Naranjo, F. El concepto de cohesión territorial. Escalas de aplicación, sistemas de medición y políticas derivadas. Boletín Asoc. Geógrafos Españoles 2009, 50, 157-172. 
37. Pita-López, M.F.; Pedregal-Mateos, B. La medición de la cohesión territorial a escala regional. Propuesta metodológica y aplicación a Andalucía. Boletín Asoc. Geógrafos Españoles 2015, 68, 31-55.

38. Cabeza-Morales, I. Cohesión territorial: Organización para reducir los desequilibrios territoriales. Bitácora Urbano Territ. 2015, 25, 51-56. [CrossRef]

39. Faludi, A. Spatial planning traditions in Europe: Their role in the ESDP process. Int. Plann. Stud. 2004, 9, 155-172. [CrossRef]

40. Faludi, A. Territorial cohesion: Old (French) wine in new bottles? Urban Stud. 2004, 41, 1349-1363. [CrossRef]

41. Faludi, A. Territorial cohesion policy and the European model of society. Eur. Plan. Stud. 2007, 41, 567-583. [CrossRef]

42. Davoudi, S. Understanding territorial cohesion. Plan. Pract. Res. 2005, 20, 433-441. [CrossRef]

43. Faludi, A. Territorial cohesion and subsidiarity under the European Union treaties: A critique of the 'Territorialism' underlying. Reg. Stud. 2013, 47, 1594-1606. [CrossRef]

44. Stilianos, A. Territorial cohesion and prospects for sustainable development: A co-integration analysis. Habitat Int. 2017, 68, 75-83.

45. Van Well, L. Conceptualizing the logics of territorial cohesion. Eur. Plan. Stud. 2012, 20, 1549-1567. [CrossRef]

46. Schön, K.P. Territorial cohesion-Current views of the commission and the member states of the European Union. In German Annual of Spatial Research and Policy; Kilper, H., Ed.; Springer: Berlin/Heidelberg, Germany, 2009; pp. 7-17.

47. Faludi, A. From European spatial development to territorial cohesion policy. Reg. Stud. 2006, 40, 667-678. [CrossRef]

48. Böhme, K.; Eser, T.; Gaskell, F. The Territorial Cohesion Principles: Position Paper to the EU Green Paper on Territorial Cohesion, Position Paper from the ARL N 78; Academic for Spatial and Planning: Hanover, Germany, 2008.

49. Böhme, K.; Doucet, P.; Komorniki, T.; Zaucha, J.; Swiatek, D. How to Strengthen the Territorial Dimension of 'Europe 2020' and the Eu Cohesion Policy; European Union and Ministry of Regional Development: Warsaw, Poland, 2011.

50. Camagni, R. Regional competitiveness: Towards a theory of territorial capital. In Modelling Regional Scenarios for the Enlarged Europe: European Competitiveness and Global Strategies; Capello, R., Camagni, R., Chizzolini, P., Frasati, R., Eds.; Springer: Berlin/Heidelberg, Germany, 2008; pp. 33-48.

51. Othengrafen, F.; Andreas, P.; Cornett, A. Critical assessment of the added value of territorial cohesion. Eur. J. Spat. Dev. 2013, 53, 1-30.

52. European Commission. Investing in Europe's Future: Fifth Report on Economic, Social and Territorial Cohesion; European Commission: Brussels, Belgium, 2010.

53. Faludi, A.; Peyrony, J. Cohesion policy contributing to territorial cohesion-Future scenarios. Eur. J. Spat. Dev. 2011, 43, 1-21.

54. Moine, A. Le territoire comme un système complexe: Un concept opératoire pour l'aménagement et la géographie. L'espace Géographique 2006, 35, 115-132. [CrossRef]

55. Elden, S. Governmentality, calculation, territory. Environ. Plan. D 2007, 25, 562-580. [CrossRef]

56. Gallardo, R.; Ortiz, D.; Ramos, F.; Ceña, F. The emergence of territories in the processes of rural development. In Knowledge, Sustainability and Bioresources in the Further Development of the Agri-Food System; Basili, C., Fanfani, R., Rastoin, J.L., Eds.; Bologna University Press: Bologna, Italy, 2007; pp. 401-423.

57. Lamara, H. Les deux piliers de la construction territoriale: Coordination des acteurs et ressources territoriales. Développement Durable Territoires 2009. [CrossRef]

58. Campagne, P.; Pecqueur, B. Processus D'émergence des Territoires Ruraux Dans Les Pays Méditerranéens: Analyse Comparée Entre 10 Pays du Nord, du Sud et de l'Est Méditerranéens; Série B. Etudes et Recherches, n. 69; CIHEAM, Options Méditerranéennes: Montpellier, France, 2012.

59. Sánchez-Zamora, P.; Gallardo-Cobos, R.; Ceña-Delgado, F. La noción de resiliencia en el análisis de las dinámicas territoriales rurales: Una aproximación al concepto mediante un enfoque territorial. Cuad. Desarro. Rural 2016, 13, 93-116. [CrossRef]

60. European Spatial Planning Observation Network 3.2. Spatial Scenarios and Orientations in Relation to the ESDP and Cohesion Policy; Third Interim Report; ESPON: Luxembourg, 2006.

61. European Spatial Planning Observation Network. Indicators of Territorial Cohesion (INTERCO); Scientific Platform and Tools Project 2013/3/2, (Draft) Final Report, Part C, Scientific Report; ESPON \& University of Geneva: Luxembourg, 2011. 
62. European Spatial Planning Observation Network (ESPON). Key Indicators for Territorial Cohesion and Spatial Planning (KITCASP); Interim Report, Version 31/10/2012; ESPON: Luxembourg, 2012.

63. European Commission. European Spatial Development Perspective (ESDP). Towards Balanced and Sustainable Development of the Territory of the European Union; European Communities: Luxembourg, 1999.

64. European Commission. Third Report on Economic and Social Cohesion. A New Partnership for Cohesion: Convergence, Competitiveness and Cooperation; European Commission: Brussels, Belgium, 2004.

65. European Commission. Fourth Report on Economic and Social Cohesion: Growing Regions, Growing Europe; European Commission: Brussels, Belgium, 2007.

66. Lin, N. Social Capital: A Theory of Social Structure and Action; Cambridge University Press: Cambridge, UK, 2001.

67. Böhme, K.; Gløersen, E. Territorial Cohesion Storylines: Understanding a Policy Concept; Spatial Foresight Brief: Luxembourg, 2011.

68. González, A.; Daly, G.; Pinch, P.; Adams, N.; Valtenbergs, V.; Burns, M.C.; Johannesson, H. Indicators for spatial planning and territorial cohesion: Stakeholder-driven selection approach for improving usability at regional and local levels. Reg. Stud. 2015, 49, 1588-1602. [CrossRef]

69. Nogués, S.; González-González, E.; Cordera, R. Planning regional sustainability: An index-based framework to assess spatial plans. Application to the region of Cantabria (Spain). J. Clean Prod. 2019, 225, 510-523.

70. Putnam, R. Bowling Alone: The Collapse and Revival of American Community; Simon and Schuster: New York, NY, USA, 2000.

71. Porter, M.E.; Ketels, H.M. UK Competitiveness: Moving to the Next Stage; Economics Department of Trade and Industry: London, UK, 2003.

72. Woolcock, M.; Narayan, D. Social capital: Implications for development theory, research, and policy. World Bank Res. Obs. 2000, 15, 225-249. [CrossRef]

73. Woolcock, M. The Place of social capital in understanding social and economic outcomes. Isuma Can. J. Policy Res. 2001, 2, 11-17.

74. Ster, G. Governance as theory: Five propositions. Int. Soc. Sci. J. 1998, 50, 27-28.

75. European Spatial Planning Observation Network (ESPON). Potentials for Polycentric Development in Europe; Report 1.1.1; ESPON: Luxembourg, 2004.

76. Cañete, J.A.; Navarro, F.; Cejudo, E. Territorially unequal rural development: The cases of the LEADER Initiative and the PRODER Programme in Andalusia (Spain). Eur. Plan. Stud. 2018, 26, 726-744. [CrossRef]

77. Reig, E. Análisis del Potencial Socioeconómico de Municipios Rurales Con Métodos No Paramétricos: Aplicación al Caso de Una Zona Leader; Documento de Trabajo n²010; Fundación BBVA: Bilbao, Spain, 2010.

78. Charnes, A.; Cooper, W.W.; Rhodes, E. Measuring the efficiency of decision-making units. Eur. J. Oper. Res. 1978, 2, 429-444. [CrossRef]

79. Callens, I.; Tyteca, D. Towards indicators of sustainable development for firms. A productive efficiency perspective. Ecol. Econ. 1999, 28, 41-53. [CrossRef]

80. Reig-Martínez, E.; Gómez-Limón, J.A.; Picazo-Tadeo, A.J. Ranking farms with a composite indicator of sustainability. Agric. Econ. 2011, 42, 561-575. [CrossRef]

81. Hashimoto, A.; Kodama, M. Has livability of Japan gotten better for 1956-1990? A DEA approach. Soc. Indic. Res. 1996, 40, 359-373. [CrossRef]

82. Mahlberg, B.; Obersteiner, M. Remeasuring the HDI by Data Envelopment Analysis; Interim Report n IR-01-069; International Institute for Applied Systems Analysis: Luxembourg, 2001.

83. Despotis, D.K. Improving the discriminating power of DEA: Focus on globally efficient units. J. Oper. Res. Soc. 2002, 53, 314-323. [CrossRef]

84. Despotis, D.K. A reassessment of the human development index via data envelopment analysis. J. Oper. Res. Soc. 2005, 56, 969-980. [CrossRef]

85. Sánchez-Zamora, P.; Gallardo-Cobos, R.; Ceña-Delgado, F. El medio rural andaluz frente a la crisis económica: Un análisis de los factores de resiliencia territorial. Econ. Agrar. Recur. Nat. 2014, 14, 27-56. [CrossRef]

86. Cooper, W.W.; Seiford, L.M.; Tone, K. Data Envelopment Analysis: A Comprehensive Text with Models, Applications, References and DEA-Solver Software, 2nd ed.; Springer-Press: New York, NY, USA, 2007.

87. Stewart, T.J. Relationships between Data envelopment analysis and multicriteria decision analysis. J. Oper. Res. Soc. 1996, 47, 654-665. [CrossRef] 
88. Rizzi, P.; Graziano, P.; Dallara, A. The regional competitiveness: An alternative approach. Riv. Int. Sci. Soc. 2015, 3, 307-366.

89. Crescenzi, R.; Luca, D.; Milio, S. The geography of the economic crisis in Europe: National macroeconomic conditions, regional structural factors and short-term economic performance. Camb. J. Reg. Econ. Soc. 2016, 9, 13-32. [CrossRef]

90. Schneiderbauer, S.; Pedoth, L.; Zhang, D.; Zebisch, M. Assessing adaptive capacity within regional climate change vulnerability studies-An Alpine example. Nat. Hazards 2013, 67, 1059-1073. [CrossRef]

91. Tran, L.; O'Neill, R.V.; Smith, E.R. Spatial pattern of environmental vulnerability in the Mid-Atlantic region, USA. Appl. Geogr. 2010, 30, 191-202. [CrossRef]

92. González-González, E.; Nogués, S. Long-term differential effects of transport infrastructure investment in rural areas. Transp. Res. A Pol. 2019, 125, 234-247. [CrossRef]

(C) 2020 by the authors. Licensee MDPI, Basel, Switzerland. This article is an open access article distributed under the terms and conditions of the Creative Commons Attribution (CC BY) license (http://creativecommons.org/licenses/by/4.0/). 